\author{
Rafał Solewski \\ Faculty of Art, Pedagogical University in Kraków \\ rafal.solewski@up.krakow.pl
}

\title{
IDEALISTIC PHILOSOPHY OF PARTICIPATION AND CONTEMPORARY ART. SELECTED EXAMPLES OF POLISH ART AT THE TURN OF THE TWENTY FIRST CENTURY
}

\begin{abstract}
The article begins with elements of the idealistic philosophy of participation. The introduction includes both Plato's thought regarding the possibility of participating in the world of ideas and the concepts of being (including the Absolute Being), acting and existence of Saint Thomas Aquinas. Finally, the notion of religious faith in participating in God's truth and love is discussed. The examples of works by Janusz Orbitowski, Grzegorz Sztabiński, Mirosław Bałka, Sebastian Wywiórski and Zbigniew Libera are described then as contemporary artistic attempts to participate in the metaphysical reality. The participation not only occurs thanks to the very metaphysical nature of art, but it is also the content and theme of works. Artists address the issues of being, essence, act, ideal pattern, the idea of writing, eternity, love relationship as participation in the idea of the Good. The poetic use of symbols and paradoxes also serves to relate to metaphysics. It is precisely poetics that is ultimately indicated as a way of participating in the metaphysical reality clearly present in contemporary visual arts.
\end{abstract}

Keywords: philosophy of participation, being, act, geometric abstraction, critical art, symbol, paradox, poetry

The philosophy of participation assumes that beings existing in the material world are also involved in a metaphysical reality. ${ }^{1}$ There is a special relationship between two spaces. Ideas, the eternal reasons (rationes aeternae), the Absolute, God exist essentially and permanently in the material world and specific beings but through similarity, imitation, emanation, transcendence or condition of being given and being a result of divine creative activity. This

1 See: Z. J. Zdybicka, Partycypacja [in:] Powszechna Encyklopedia Filozofii, http://www.ptta.pl/ pef/pdf/p/partycypacja.pdf (accessed: 18 September 2018). 
means that all the material beings participate in some way in the metaphysical Absolute Being. Therefore the metaphysics is understood as "rationally valid and intellectually verifiable cognition of the world existing in reality (including the affirmation of the Absolute Being), aimed at discovering the ultimate cause of its being, whose traces human reason finds in empirically available objects". ${ }^{2}$ The Platonic and Neo-Platonic tradition pointed to independence, unity, perfection, constant immutability and eternal durability of metaphysical ideas. The Good and the Beauty standing at the top of their hierarchy were recognized as the attributes of God. Moreover, St. Augustine explicitly wrote about participation in the truth, that is, the pattern existing in God's mind. St. Thomas emphasizes that every being participates in the Absolute Being:

"Now, since God is being itself by His own essence, created being must be his proper effect [...] Therefore, as long as a thing has being, so long must God be present to it, according to its mode of being. But being is innermost in each thing and most fundamentally inherent in all things [...]. Hence it must be that God is in all things and innermostly." 3

The specific "finite" creature participates in the essence (essentia) by the act of being (esse). The existence is the act of being.

On the other hand, Aristotle's logic indicates that "accidents", the features of things inhere or participate in a substance. This gave rise to the universal claim that the features of things are involved in what is general. The "accidents" of material substance, however, do not affect the essence.

Ultimately, it is assumed that the philosophy of participation accepted the distinctions between being and existence, potency and act, substance and accidents, matter and form.

In a religious belief there is possible a pantheistic or transcendental view on participation: "we participate in relational union with God by means of our embodiedness, not in spite of it. God is all around us, in us, and through us - and yet God is not us and we are not God. We must tune in our various senses and participate with God". ${ }^{4}$ On the other hand, the conception of theosis reminds that

2 M. A. Krapiec, A. Maryniarczyk, Metafizyka, http://www.ptta.pl/pef/pdf/m/metafizyka.pdf (21 March 2016); A. Maryniarczyk, Transcendentalia [in:] Powszechna Encyklopedia Filozofii, http://www.ptta.pl/pef/pdf/t/transcendentalia.pdf (16 June 2013).

3 St. Thomas Aquinas, Summa Theologica, Ia, 8, 1, English Dominican Province Translation Edition, Benziger Bros., New York, 1947-1948, at sacred-texts.com, http://www.sacred-texts. com/chr/aquinas/summa/sum011.htm (18 September 2018).

4 C. J. Conniry, Jr., Participation in God. Chapter from Relational Theology, George Fox Evangelical Seminary, 2012, p. 28, https://digitalcommons.georgefox.edu/cgi/viewcontent.cgi?referer=https://www.google.pl/\&httpsredir $=1 \&$ article $=1023 \&$ context=gfes $(21$ September 2018). 
"humans were created in God's <image> and <likeness>. Many early Christians said that despite sin, humans retain God's image but lost God's likeness. Through redemption in Christ and the sanctifying work of the Holy Spirit, human beings

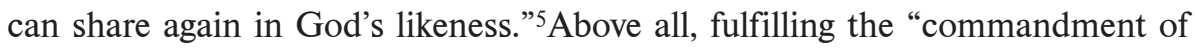
love" allows believers to participate in God's nature of love.

Throughout the history, participation in the "higher reality" was considered elemental not only for sacred or religious art. This was the base of the metaphysical nature of art and its fundamental principle. ${ }^{6}$ The crucial purpose of art was to reveal the level of ideas. Art exposed especially the idea of beauty what can be understood as participating in it. Philosophers also saw in the work of art a truth of the pure being, as the artwork was the example of a "purposeless being". Relations with beauty and truth therefore constituted the sense of art.

It may seem that participation and relation are understood differently today. Nevertheless, in contemporary art, the need to either participate in the Absolute Being or to observe the relationship between material and metaphysical reality can be still noticed.

For instance, the generation of Polish artists developing abstract art and exploring its cognitive abilities seems to continue the art of metaphysical participation.

Janusz Orbitowski's work titled 15/97 (the fifteenth work painted in 1997, size $110 \times 80 \mathrm{~cm}$ ) was painted in acrylic on canvas in black, white and grey. The entire surface is covered with a structure of closely-fitting, vertically-aligned rectangles. There are 408 of them. Each one is filled with black paint with various degrees of saturation. Some of the rectangles are completely black. Most, however, are fuzzy black, turned into grey or with stains on a white surface. The fillings resemble prints of an organic matter. They also evoke associations with rough tree bark, ridges of leaves or shells, an animal skeleton... The title of the series of paintings is significant: Traces.

However, the entire surface of the image is intersected by six diagonal lines. Those of the rectangles that are intersected by one of the lines have two different fillings. The picture looks like a mosaic that has been cut diagonally six times and then folded back to retain the pattern, structure and order. On the other hand, it could be just a shimmering, white and black ornament arranged in seven wide stripes leaning to the right.

5 Ibidem.

6 See: W. Stróżewski, O metafizyczności w sztuce [in:] idem, Wokót piękna. Szkice z estetyki, Universitas, Kraków 2002, pp. 93-134.

7 See: O. Marquard, Gesamtkunstwerk und Identitätssystem. Überlegungen im Anschluß an Hegels Schellingkritik : "Aesthetica und Anaesthetica". Philosophische Überlegungen, Fink München 2003, p. 100. 
Another, later example (Relief 11/02, acrylic, fibreboard, cardboard; size $1 \times 1 \mathrm{~m}$ ) features seventeen horizontal rows of adjoining vertical rectangles, several-centimeter-long, on a smooth white surface. The rows form the wide, diagonal stripe running from the bottom left to the right upper corner. The rectangles descend deeply "pushing" into the plane or they rise above the flat surface of the main board as stairs or panels within small staircases.

As a result, the viewer must discover the diagonal axis of the composition from under the trembling, rhythmic steps. However, the inclined axis, seemingly "shifted" and "jagged", clearly appears as the basis of the compositional decision. And this is the one decision. Its determination and categorical nature are intrinsic amid the vibrating sensations. The diagonal stripe may also look like a leaning column imprinted on the plane.

In both works, the individual parts (rectangles, stripes, lines) remain in special geometric and dynamic relations that may provoke feelings of anxiety or sublimity. Perhaps it is Orbitowski's unique way of showing these relationships whose presence in the image makes it possible to express the universal element, as Mondrian believed $?^{8}$ On the other hand, the artistic construction, reflecting the "absolute need" to create, greatly affects the viewer's eye. It is the "responsive eye" that already reveals the pattern and the decisive will. The problem of a pattern was a subject constantly "examined" by the artist. The purpose of such artistic explorations was perhaps to discover the way to find (to participate in?) the ideal pattern. It would be a strong universal rule to be implemented perfectly as an imitation of the Idea in a constructive expression. The later relief shows how the expression of the decision as an act was extracted from the visual impressions by "minimalizing" synthesis.

In such activities, the viewer can notice the examination of experiences indicating only permanent patterns natural for the human mind. On the other hand, the metaphysically sensitive observer can also see an attempt to study the modes of the Absolute Pattern, as well as the need to express the "act of decision" artistically. Such art would participate in the metaphysics not only through its elemental metaphysical nature, but the metaphysics would also be its basic theme. Taking up such a topic would be another way to participate in the metaphysical reality.

The suggestion of imprinting natural traces in Orbitowski's work indicates the way to participate in the space of metaphysics. The example of Grzegorz

8 See: G. Sztabiński, Dlaczego geometria? Problemy wspótczesnej sztuki geometrycznej, Wydawnictwo Uniwersytetu Łódzkiego, Łódź 2004, p. 22.

9 Achromatic contrast of white and black (tonally mediated by grey) is typical for "optical paintings" See: W. C. Seitz, The Responsive Eye, exhibition catalogue, Museum of Modern Art, New York 1965, pp. 18-19). 
Sztabiński's art stresses the non-ordinary, not obvious path to synthesize the pattern and the rule as the proper one. In The Writing of Nature (the cycle of installations developed since 1993) the artist collects and arranges fragments of wood and dry branches (found in a careful observation of the nature) as separate installations. Tiny twigs protruding in various directions and constructing naturally diverse structures are arranged on an individual sheet of white or black paper. This way, Sztabiński captures the unique letters of the alphabet of nature. Such letters are elusive to a hurried observer, untranslatable for those who see only wood in the tree and only a momentary life heading for the inevitable end in nature. Meanwhile, hieroglyphs of nature in their infinite number each time implement a paradoxical pattern. It is paradoxical because it is unique, yet it is still a pattern. The basis of syntax connecting natural letters and words in "installation utterances" is also paradoxical. There is an empty space isolating the exposed fragments of nature from each other. The observer must fill this space to form "an utterance". This way the viewer/reader may participate in the metaphysical reality by experiencing its traces as a scripture written according to a mysterious rule. As a co-constructor of the relationship between the elements of the installation, he or she "unconsciously" participates in this rule. The Writing of Nature contains both the pattern of writing and the idea of scripture. The pattern and the idea transcend nature by constantly being realized in it. The significant title of Grzegorz Sztabinski's exhibition in 2016 in Kraków was The Writing of Nature - Transcendence III. ${ }^{10}$

The pattern is deciphered by an observer as a paradox because it is simultaneously present also in a different reality, which human beings experience only through a trace in the form of the natural Writing. Nonetheless, the trace in the form of a natural scripture exists to be read. As a reader, a human being can try to participate in "a different reality and its order, which is a fleeting foundation of creation, organization, connections and disconnections, binding and liberating". ${ }^{11}$ In the ideas that "are in God to make it possible to cognize". ${ }^{12}$

Sztabiński's Writing of Nature is usually juxtaposed with paintings hanging on the walls of the gallery. These are unprimed, "natural" canvases featuring stereometric triangular forms with distinct contours in subdued white, grey and brown. Triangular pointing to what is "above" corresponds, however, with the stability of the shape of a pyramid. The very existence, categorical, obvious and

10 The exhibition at Otwarta Pracownia [Open Studio] in Kraków was presented in June 2016.

11 R. Solewski, Metaphysical cognition in hermeneutic interpretation: remarks on Grzegorz Sztabinski's The Writing of Nature - Transcendence III, "Estetyka i Krytyka", 43 (4/2016): Hermeneutics and Art, ed. Dominika Czakon, Jean Grondin, p. 135.

12 Z. J. Zdybicka, op. cit. 
orderly, is present also in the horizontal strip on canvases or a vertical block standing alone in the gallery space. The block is sometimes wrapped in a rope. It is knotted, entangled, just like a being entangled in the material world, its history and culture. Perhaps it is a symbol of the Platonic "tight chains" that make it impossible for a human trapped in the cave to cognize the very ideas of which "eternity", however, expresses the geometric form (and Sztabinski as the philosopher wrote about Plato and geometry). ${ }^{13}$ Paradoxically, the idea would be trapped here. The work would directly indicate the difficulty of human relations with metaphysical reality. Perhaps Sztabiński's entire artistic expression can be described as an attempt to participate in the essence by the act of visual reading of the difficult relational situations?

The artists of younger generations also face similar challenges of "participation in the essence by the very existence". There are eight salt cylinders placed in massive concrete containers by Mirosław Bałka in the sculpture $7+1$ (1998 / 2011). The cylinders are not high $(30 \mathrm{~cm})$ but large in diameter (they may resemble columns cut off smoothly and on one level at their base or large round stone "slices"). The first circular block rotates slowly. Finally, the entire composition of eight containers with a meter-to-meter base set in one straight line makes a monumental impression. The brown round "slices" with grey-white streaks are made of salt from the Kłodawa mine and the impurities emphasize the natural origin and mineral richness. Moreover, the streaks are what differentiates the appearance of each individual cylinder. The museum description indicates: "Salt is symbolic of wealth, of everyday utility; but also of bitterness and bad taste. Concrete stands for solidity, security, but also confinement and limitation." ${ }^{14}$ There is also information important for hermeneutical interpretation. The artwork was created for the corporation that mines and sells salt. The installation uses the fact that salt used to be a form of currency and the shape of the flat cylinders resembles coins. It is significant that the first round shape is mobile. The coin is "in circulation".

On the other hand, the raw and rough materiality of the salt in the massive blocks evokes the notion of essence. Perhaps it is the most important symbolic meaning recounted in the words: "You are the salt of the earth. But if the salt loses its saltiness, how can it be made salty again? It is no longer good for anything, except to be thrown out and trampled underfoot." 15

13 See: G. Sztabiński, op. cit., p. 19.

$147+1$, https://en.mocak.pl/artist/562/7-1-balka (19 September 2018).

15 Matthew 5:13, Bible. The New International Version, Biblica, Colorado Springs 2011; https:// www.biblegateway.com/passage/?search=Matthew+5\%3A13-16\&version=NIV (19 Septmeber 2018). 
The viewer may use such a meaning to complement the symbol in its entirety (in accordance with the original meaning of "symbolon" stressed by Gadamer. $)^{16}$ It is the manner to experience the complementary, uniting way of participating. Since it is possible to cognize "the One" in the uniting act. What's more, in Bałka's sculpture the interpreted matter of unity is literally the essence symbolized by salt. It is the essence that may seem diversified by the "streaky" appearance and movement of one of the parts, but it is still one as a salt. And it is also s matter subjected to the regular order of hard geometric concrete containers. The containers have the symbolic meaning of the decisive will. As the salt is the essence, the containers are also the act giving the form. It means that the relation between salt cylinders and concrete containers symbolizes the relation between the essence and an act.

The minimalist sublimity of the monumental installation shows both the essence of salt matter as the infinite being at all and the "concrete" act of existence. It is finally experienced by a viewer who, by the completing interpretation of symbols, is involved in action. As if the viewer participated by observation, interpretation and "cognition in completion" 17 in the act of being (esse) forming the matter and bringing it into motion.

The eternity as a space of an infinite being and "an ultimate aim" is still a challenge for the youngest artists. The installation Continuum from the Unobvious Subtlety of Movement cycle $(360 \times 200 \times 30 \mathrm{~cm} /$ acrylic on PCV banner, aluminum, electric engine) was presented by Sebastian Wywiórski in the Chapel in Ammersbeck in 2016.

There was a long PVC belt ( $1.6 \mathrm{~m}$ wide and $7 \mathrm{~m}$ long) painted green and stretched on aluminium rollers. It was moving very slowly (wrapping around rollers) on the principle of an endless loop. Subtle differences in green saturation occurred during the movement of the belt. The barely perceptible motion was the result of the work of electric motors and special transmission system. The quiet hum of the drive was part of the immersive experience of the installation. The viewer of the installation became the recipient using various senses in his experience and cognition. There was experienced in such an immersion the relationship between mechanical hum of measurable time and quiet "the Green" repeating continuously and so symbolically infinite, ubiquitous, overwhelming, transcendent.

16 See: H.-G. Gadamer, The Relevance of the Beautiful. Art as play, symbol, and festival, transl. Nicholas Walker, London: Cambridge University Press, 1986, pp. 31-32.

17 Hans-Georg Gadamer, Ende der Kunst? Von Hegels Lehre vom Vergangenheitscharakter der Kunst bis zur Anti-Kunst von Heute [in:] idem, Aesthetik und Poetik, Gesammelte Werke, vol 8, p. I Kunst als Aussage, J. C. B. Mohr (Paul Siebeck), Tübingen 1993, p. 219. 
What was, therefore, the subject of cognition? The artist himself quoted philosophers and reflections on time and eternity in his commentary on the own work: "according to Plato, time is the moving image of eternity, lasting in unity, but moving according to number. Time <moves according to number>, but is designated according to a certain unity. [...] Plato calls to mind Eastern images according to which time has the structure of a circle - the history of the world is a history of eternal returns. The author of Timaeus advanced the conjecture that the heavenly bodies will someday once again have the very configuration which they had at some time in the past, the cycle of the universe will close and everything will begin to occur again. The never-ending repetition of events is as close to eternity as the world can get"18.

In the artist own interpretation "the Repeatability is to become a chance for getting closer to eternity" ${ }^{19}$ Perhaps it is consistent with this interpretation to indicate that the experience (the seeing and the hearing) of the passage of measurable time allows a human (a recipient) to experience time's finiteness and littleness in the face of quiet eternity. The realization of this situation is an elusive "briefest of the moments" of participation in the eternity, holding back time, world, existence. Just for the blink of an eye only the silent eternity remains and with it the Absolute Being. It is an attempt to cognize metaphysically caused by Wywiórski's work. It's significant that the installation functioned in a purposely chosen space of the chapel.

It seems that the application of the idealistic philosophy of participation to the contemporary art is possible especially in the case of abstract works. However, also the art called critical, often interpreted in context of social relations and participation in social life, may be understood as the participation in the metaphysical space of ideas.

In the video installation Obrzędy intymne [Intimate Rites] (1984) ${ }^{20}$ Zbigniew Libera filmed his over 90-year-old, frail grandmother, Regina. In his short film (11'42'), he shows feeding, washing and changing diapers with naturalistic precision. The caretaking is done exclusively by the artist, who was very young at the time. Although everything is happening in silence, the eponymous intimacy is missing (this is a subversive use of the expected meanings to convey the messages that criticize these meanings, specific to critical art). ${ }^{21}$ The anato-

18 M. Heller, Philosophy in Science. An Historical Introduction, Springer-Verlag Berlin Heidelberg, 2011, p. 36 [in:] S. Wywiórski, Self-commentary. Description of Artistic Accomplishment, post-doctoral dissertation, Kraków 2017, p. 50.

19 S. Wywiórski, op. cit., p. 50.

20 Zbigniew Libera, Obrzędy intymne, http://filmoteka.artmuseum.pl/?1=0\&id=718 (13 July 2013).

21 Artistic subversion clearly manifests meanings, opinions and feelings. Subtle accent or shift, however, shows the real disapproval of them and suggestion of the replacement, revision, change or improvement. Such an idea is not always fully conscious. See: Subversion, http:// en.wikipedia.org/wiki/Subversion (15 January 2014). 
mical details are shown, old and ugly, just like the grandmother's vulnerability. The actions of the young caregiver can be viewed as embarrassing, traumatic and abnormal performance of unpleasant duties. This video installation criticizes and contests the system as a crucial challenge for critical art. What is criticized, however, is not so much the necessity of care (which, as one might say, the inefficient system fails to provide) but the system of thinking in which care for an infirm person is perceived as a burden, something ugly, embarrassing. In such a system of thinking, there is no place for intimacy. However, in line with such a criticism, this short film can be interpreted as an expression of love. Love understood as a desire to do something good for another and perceived as a way of finding one's identity in relation to another. "Desire for the Good" important in Platonic idealism means participating in the idea of the Good. As the act being undertaken in relation to another it is love. Participation in love is not easy, as Libera's film demonstrates. In contrary to human expectations, love is the most present in toil and sacrifice, not in exciting enjoyment. This is also the meaning of paradox stated in Libera's video. However, it is of a metaphysical character. Significantly, the Libera's film is silent. The Good is the attribute of God and love is participation in God's act. And God reveals himself in silence.

The described examples show participation in the metaphysical nature of being by the existence itself. There are the works presented and the works "are not nothing". ${ }^{22}$ Most examples emphasize being existing in their own existence in various ways. In the works by Orbitowski, Bałka, Wywiórski it has a clearly sublime character. The relation as "participating in" or "relationship between" appears also at different levels and in different ways. All the examples reveal the level of ideas thanks to the metaphysical nature of art. It occurs in the reception of works thanks to the perfection of artistic execution, the harmony and order seeking for the ideal pattern (Orbitowski, Sztabiński), the intended impressive, responsive and immersive effect stressing the transcendence of both the essential being and the act (Orbitowski, Sztabiński, Bałka, Wywiórski), but it is also present in a poetic composing of the content using symbols, paradoxes and subversion. The relationship between individual elements of the works itself can symbolically indicate relationality as the essence of the philosophy of participation (Orbitowski, Sztabiński, Bałka, Libera). On the other hand, the paradox is found as transcending human expectations, habits, knowledge and understanding, as in works by Orbitowski, Sztabiński and Libera. Both the coincidentia oppositorum and the uniting integration of the symbol reveal another, metaphysical space. It is the space of the Absolute Being, unlimited by the categories of time, space, vision, understanding... There are only traces of Its

22 D. A. Siedell, God in the Gallery. A Christian Embrace of Modern Art, Baker Academic, Grand Rapids 2008, p. 49, see also: 89-92. 
essence and Its act of existence to be experienced by human beings. And these traces are visibly indicated by the described works. However, a human being wants to participate in the metaphysical whole. Perhaps such a metaphysical cognition is closer in the understanding of the poetry of artworks, as the artists suggest?

\section{BIBLIOGRAPHY}

$7+1$, https://en.mocak.pl/artist/562/7-1-balka (19.09. 2018).

St. Thomas Aquinas, Summa Theologica, English Dominican Province Translation Edition, Benziger Bros., New York, 1947-1948, at sacred-texts.com, http://www.sacred-texts.com/chr/ aquinas/summa/sum011.htm, (18. 09. 2018).

Bible. The New International Version, Biblica, Colorado Springs 2011; https://www.biblegateway. com/passage/?search=Matthew+5\%3A13-16\&version=NIV (19.09. 2018).

Charles J. Conniry, Jr., Participation in God. Chapter from Relational Theology, George Fox Evangelical Seminary, 2012, p. 28, https://digitalcommons.georgefox.edu/cgi/viewcontent.cgi?refere$\mathrm{r}=\mathrm{https}: / /$ www.google.pl/\&httpsredir=1\&article=1023\&context=gfes $(21.09 .2018)$.

Hans-Georg Gadamer, Ende der Kunst? Von Hegels Lehre vom Vergangenheitscharakter der Kunst bis zur Anti-Kunst von Heute in: idem, Aesthetik und Poetik, Gesammelte Werke, vol 8, p. I Kunst als Aussage, J. C. B. Mohr (Paul Siebeck), Tübingen 1993, pp. 206-220.

Hans-Georg Gadamer, The Relevance of the Beautiful. Art as play, symbol, and festival, transl. Nicholas Walker, London: Cambridge University Press, 1986.

Michał Heller, Philosophy in Science. An Historical Introduction, Springer-Verlag Berlin Heidelberg, 2011.

Mieczysław A. Krąpiec, Andrzej Maryniarczyk, Metafizyka, [in:] Powszechna Encyklopedia Filozofii, http://www.ptta.pl/pef/pdf/m/metafizyka.pdf (21. 03. 2016).

Zbigniew Libera, Obrzędy intymne, http://filmoteka.artmuseum.pl/?1=0\&id=718 (13. 07. 2013).

Andrzej Maryniarczyk, Transcendentalia [in:] Powszechna Encyklopedia Filozofii, http://www. ptta.pl/pef/pdf/t/transcendentalia.pdf (21.03. 2016).

William C. Seitz, The Responsive Eye, exhibition catalogue, Museum of Modern Art, New York 1965.

Daniel A. Siedell, God in the Gallery. A Christian Embrace of Modern Art, Baker Academic, Grand Rapids 2008.

Rafał Solewski, Metaphysical cognition in hermeneutic interpretation: remarks on Grzegorz Sztabiński's The Writing of Nature - Transcendence III, "Estetyka i Krytyka”, 43 (4/2016): Hermeneutics and Art, ed. Dominika Czakon, Jean Grondin, pp. 125-144. 
Subversion, http://en.wikipedia.org/wiki/Subversion (15. 01. 2014).

Grzegorz Sztabiński, Dlaczego geometria? Problemy wspótczesnej sztuki geometrycznej, Wydawnictwo Uniwersytetu Łódzkiego, Łódź 2004.

Sebastian Wywiórski, Self-commentary. Description of Artistic Accomplishment, post-doctoral thesis print, Kraków 2017.

Zofia J. Zdybicka, Partycypacja [in:] Powszechna Encyklopedia Filozofii, http://www.ptta.pl/pef/ pdf/p/partycypacja.pdf (18. 09. 2018).

\section{IDEALISTYCZNA FILOZOFIA PARTYCYPACJI I SZTUKA WSPÓŁ- CZESNA. WYBRANE PRZYKŁADY SZTUKI POLSKIEJ NA PRZE- ŁOMIE XX I XXI WIEKU (streszczenie)}

Tekst rozpoczyna wprowadzenie w idealistyczną filozofię partycypacji. Zawiera ono przypomnienie o myśli Platona dotyczącej możliwości uczestniczenia w świecie idei, o koncepcjach bytu (w tym Bytu Absolutnego), aktu i egzystencji w filozofii Św. Tomasza z Akwinu oraz o religijnej wierze w uczestniczenie w prawdzie i miłości Boga. Opisane dalej przykłady dzieł Janusza Orbitowskiego, Grzegorza Sztabińskiego, Mirosława Bałki, Sebastiana Wywiórskiego * i Zbigniewa Libery zinterpretowane zostają jako współczesne próby artystycznego uczestniczenia w rzeczywistości metafizycznej. Dzieje się to przez samą metafizyczność sztuki oraz przez podejmowanie w treści i formie dzieł zagadnień bytu, esencji, akt, idealnego wzoru, idei pisma, wieczności, relacji miłosnej jako uczestniczenia w idei Dobra. Relacji z metafizyką służy także poetyckie wykorzystanie symbolu i paradoksu. Właśnie poetyckość zostaje ostatecznie wskazana jako sposób partycypowania w rzeczywistości metafizycznej wyraźnie obecny we współczesnych sztukach wizualnych.

Słowa kluczowe: filozofia partycypacji, byt, akt, abstrakcja geometryczna, sztuka krytyczna, symbol, paradoks, poezja 